\title{
Specific Chromosomal Affinity of a Resistance Factor
}

\author{
By L. E. PEARCE* AND ELINOR MEYNELL \\ M.R.C. Microbial Genetics Research Unit, \\ Hammersmith Hospital, Ducane Road, London, W. I2
}

(Accepted for publication 8 July 1967)

\begin{abstract}
SUMMAR Y
$\mathbf{R}$ factors, responsible for transmissible drug resistance in Enterobacteriaceae, convert their hosts into donors of genetic material, but fewer recombinants for chromosomal genes are produced than with $\mathrm{F}$. For one $\mathrm{R}$ factor, at least, this was merely a consequence of less frequent conjugation. With a mutant where conjugation was not repressed in contrast to the wild type, this $\mathrm{R}$ factor, $\mathrm{Rr}$, was shown to behave like an $\mathrm{F}^{\prime}$ factor and to transfer the bacterial chromosome at high frequency from a fixed origin near the try genes.
\end{abstract}

\section{INTRODUCTION}

The factors responsible for transmissible drug resistance in Enterobacteriaceae resemble the $\mathrm{F}$ factor of Escherichia coli $\mathrm{K} \mathrm{I} 2$ in conferring on their hosts the ability to donate the factor by conjugation to other bacteria (Watanabe, 1963). The existence of $\mathrm{F}$ was originally detected by the ability of an $\mathrm{F}^{+}$bacterium to produce genetic recombinants with an $\mathrm{F}^{-}$recipient (Lederberg, Cavalli \& Lederberg, I952; Hayes, 1953), but the presence of an R factor may be detected directly by transfer of the drugresistance determinants as a part of the factor itself. The recipient is thus converted to a drug-resistant bacterium at the same time as it in turn becomes able to conjugate and to pass on its resistance. $\mathrm{R}$ factors occasionally bring about transfer of chromosomal genes and the formation of genetic recombinants between bacteria both of which are $\mathrm{F}^{-}$(Sugino \& Hirota, I962). In contrast to the situation with F, however, chromosomal recombinants appear at very low frequency, corresponding ordinarily only to about $10^{-7}$ to $10^{-8}$ of the $\mathrm{R}^{+}$population instead of $1 \mathrm{IO}^{-4}$ to $\mathrm{IO}^{-5}$ of an $\mathrm{F}^{+}$population.

Several different $\mathrm{R}^{+}$strains of $E$. coli K 12 58-I6I/sp met ${ }^{-}$were tested for their ability to give genetic recombinants with an $\mathrm{F}^{-}$recipient, $\mathrm{J}$ 6-2 pro $^{-}$his ${ }^{-}$try $\mathrm{y}^{-}$, and one of the factors, $\mathrm{R}_{\mathrm{I}}$, was remarkable for the relatively large number of try ${ }^{+}$recombinants produced. While $\mathrm{pro}^{+}$and $\mathrm{his}^{+}$recombinants occurred at a frequency of $\mathrm{IO}^{-7}$ to $\mathrm{IO}^{-8}$ per $\mathrm{R}^{+}$donor cell, there were more than $\mathrm{IO}^{-5}$ try $y^{+}$colonies. Tryptophan independence was not conferred, like drug resistance, by the $\mathrm{R}$ factor itself; crosses between $\mathrm{R} \mathrm{I}^{+} \mathrm{F}^{-}$bacteria and a recipient strain mutated in the genes $p y r F$, try and pur $B$ (Signer, Beckwith \& Brenner, 1965; see Fig. I) showed that it was indeed this region of the bacterial chromosome that was transferred.

Almost every $\mathrm{F}^{+}$bacterium can conjugate, but with other factors conjugation is

* Present address: New Zealand Dairy Research Institute, P.O. Box 1204, Palmerston North, New Zealand. 
repressed and happens with only a minority of the cells (Ozeki, Stocker \& Smith, 1962; Meynell \& Datta, 1966a; Meynell \& Lawn, 1967). Since, when conjugation occurs it only occasionally leads to chromosome transfer, when it is infrequent the numbers of genetic recombinants must be correspondingly small. Recombination with R I was first studied with the wild-type $\mathrm{R}$ factor, but the nature of the preferential transfer of the try region could be investigated only after the isolation of a derepressed mutant, R I drd (Meynell \& Datta, 1967), with which conjugation occurred about as often as with $\mathrm{F}$, and which therefore allowed the rates of production of different classes of chromosomal recombinants with the two sex factors to be directly compared.

\section{METHODS}

Culture media. Defined medium was the mineral salts medium described by Tatum \& Lederberg (1947), with the omission of asparagine and solidified with $\mathrm{I} \cdot 5 \%$ (w/v) Davis N.Z. agar. In a few experiments, M9 medium (Adams, 1959) was used. These were appropriately supplemented with amino acids, purines and pyrimidines at $20 \mu \mathrm{g} . / \mathrm{ml}$., thiamine at I $\mu \mathrm{g} . / \mathrm{ml}$. and sugars used as carbon source at $0.2 \%(\mathrm{w} / \mathrm{v})$.

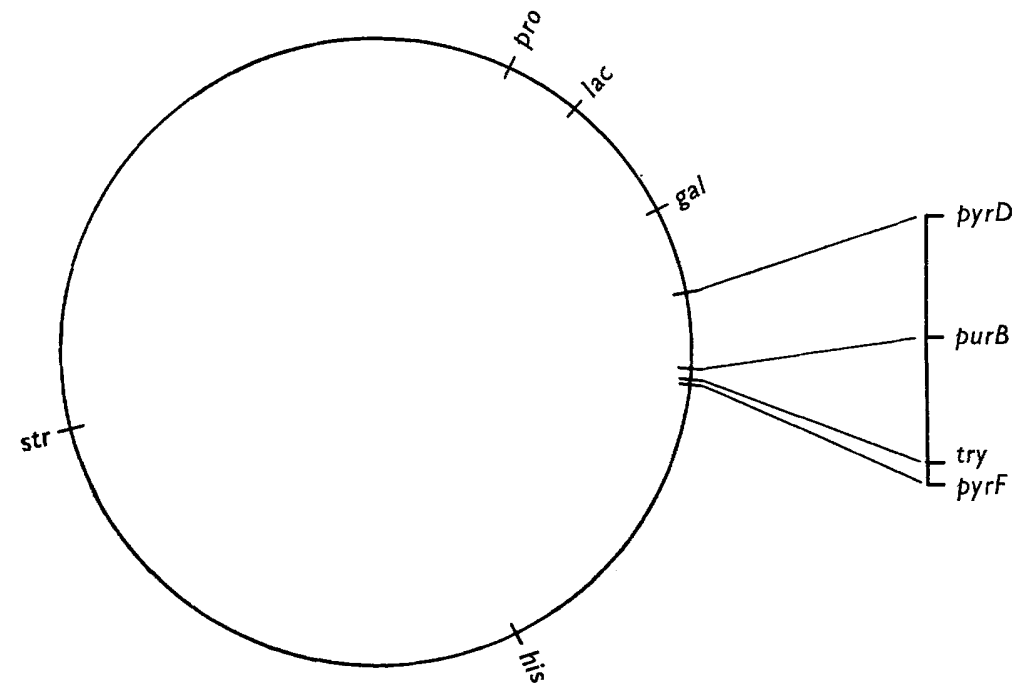

Fig. I. The genetic map of Escherichia coli showing the loci which are referred to.

Broth was either Oxoid broth No. 2, or L-broth (Lennox, 1955) adjusted to $\mathrm{pH} 74^{4}$; for nutrient agar, these were solidified with $1 \cdot 35 \%(\mathrm{w} / \mathrm{v})$ Davis N.Z. agar.

Bacteria. These were all derivatives of Escherichia coli $\mathrm{KI} 2$ and are described in Table I.

$R$ factor. R I (Meynell \& Datta, I966a) confers resistance to chloramphenicol, kanamycin, ampicillin, streptomycin and sulphonamide. Mutants of R I whose conjugation function is no longer repressed have been isolated by Meynell \& Datta (1967), and one of these, $\mathrm{R} I d r d-19$, was used in addition to the wild-type $\mathrm{R}$ factor. The $\mathrm{R}$ factor was introduced into a strain by conjugation, selecting for resistance to chloramphenicol $(25 \mu \mathrm{g} . / \mathrm{ml}$.) added to defined medium supplemented to allow growth of the recipient, but not the donor, strain. 
Bacterial crosses and measurements of frequency of $R$ factor transfer. Donor and recipient strains were grown overnight in broth without shaking. Next day, the culture of the donor strain was diluted $\mathrm{I} / \mathrm{IO}$ in fresh broth and incubated for $2 \mathrm{hr}$ without aeration until the bacterial concentration reached $2-5 \times 10^{8} / \mathrm{ml}$. The temperature of incubation greatly affected the donor ability of the culture; at $35^{\circ}$ or less very little chromosome or $\mathrm{R}$ transfer occurred. Mating mixtures contained $0.5 \mathrm{ml}$. of the donor

Table I. Bacterial strains: all derivatives of Escherichia coli $\mathrm{KIZ}$

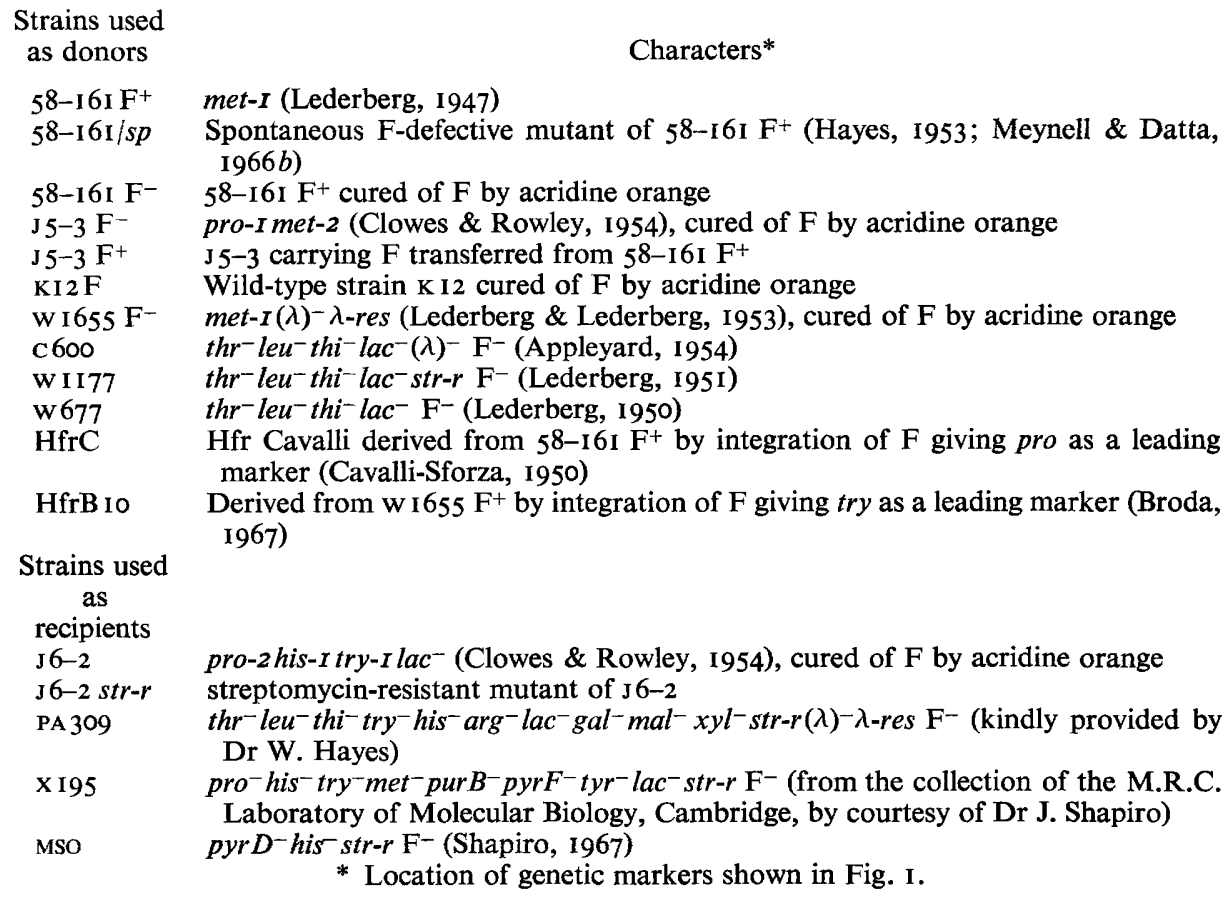

culture and $4.5 \mathrm{ml}$. of the overnight recipient culture, and were rotated at $37^{\circ}$ in a $\frac{1}{2}$ oz. screw-cap bottle on an inclined turntable revolving at $33 \mathrm{rev} . / \mathrm{min}$. With wildtype $\mathrm{R}_{\mathrm{I}}$ and with $\mathrm{F}^{+}$donors, the mixture was incubated for $60 \mathrm{~min}$. and dilutions in buffer were then plated on appropriate media to isolate recombinants. In all except the preliminary experiments with R I $d r d-19$, the mating mixture was incubated for only $5 \mathrm{~min}$. to allow cell-to-cell contacts to form, and was then gently diluted $\mathrm{I} / \mathrm{IOO}$ into fresh warm broth (de Haan \& Gross, 1962). This was held at $37^{\circ}$ either for $60 \mathrm{~min}$. or for the time stated in the experiments where mating was interrupted. Before plating, the mating pairs were separated by agitating the sample with a 'Whirlimixer' (Fisons Scientific Apparatus Ltd., Loughborough, Leicestershire). Samples were plated in a layer of soft agar, using $2.5 \mathrm{ml}$. volumes of $0.6 \%(\mathrm{w} / \mathrm{v})$ agar in water; control experiments showed that as many recombinant colonies were produced by this method as by spreading the sample on the surface of the medium. Ability to synthesize a given nutrient was tested by omitting it from an otherwise complete defined medium; ability to utilize a particular sugar was tested by providing it as sole energy source.

Contraselection against the $R^{+}$donor strain with streptomycin. The bacteria used as recipients were one-step mutants to high level streptomycin resistance and, although 
streptomycin is one of the antibiotics to which the $\mathrm{R}$ factor $\mathrm{R}$ I confers resistance, the maximum concentration which allows normal growth of $\mathrm{R} \mathrm{I}^{+}$bacteria on nutrient agar is about $20 \mu \mathrm{g} . / \mathrm{ml}$. The concentration of streptomycin initially used to select against the donor strain was $250 \mu \mathrm{g}$. $/ \mathrm{ml}$., but when this was shown to be insufficient to abolish growth of $J_{5-3}\left(R_{I}\right)$ on defined medium (Pearce \& Meynell, I968), the concentration was increased to $5000 \mu \mathrm{g}$. $/ \mathrm{ml}$., which was the least concentration needed to prevent completely the growth of the $\mathrm{R} \mathrm{I}^{+}$donor, but which still allowed normal growth of the highly streptomycin-resistant recipient strains.

\section{RESULTS}

\section{Selected cases of recombinants}

In preliminary tests of $\mathrm{R}^{+}$donors with a recipient strain $\mathrm{J}^{6-2}$ pro- $^{-}$try-his- $\mathrm{str}^{-}$the factor $\mathrm{R} \mathrm{I}$ gave $\mathrm{IO}^{-7}$ to $\mathrm{IO}^{-8} \mathrm{pro}^{+}$and $\mathrm{his}^{+}$recombinants per donor cell, while rry $^{+}$ colonies appeared much more frequently, at a rate of $\mathrm{IO}^{-4}$ to $\mathrm{IO}^{-5}$. The original donor strain, 58-I6I/sp met ${ }^{-}$carries a defective F factor (Meynell \& Datta, 1966b) which might have been responsible for the observed recombination, so $\mathrm{R}$ I was re-tested in strain $\mathrm{J}^{-3}-3$ pro $^{-}$met $^{-}$, an $\mathrm{F}^{-}$strain cured of $\mathrm{F}$ by acridine orange. Since donor and recipient were both pro- $^{-}$here as a result of mutations in closely linked genes, only the numbers of his ${ }^{+}$and try $^{+}$recombinants could be compared; however, in crosses between J 5-3 (R I) and J6-2 str-r large numbers of try ${ }^{+}$colonies were again obtained (Table 2). Their try ${ }^{+}$gene was not an integral part of the $\mathrm{R}$ factor itself because about 200 times more recipients became drug-resistant than become tryptophan-independent, while any $t r y^{+}$strain was converted into a high-frequency donor of the character when $\mathrm{R} \mathrm{I}^{+}$derivatives were selected for drug-resistance alone. While most try ${ }^{+}$recombinants were drug-resistant, 17 out of 423 were $R^{-}$; in addition, $R^{-}$segregants of $\mathrm{R}+$ try ${ }^{+}$recombinants remained try ${ }^{+}$.

In the first crosses with strain J6-2 str-r pro-his- try- as recipient, only $250 \mu \mathrm{g} . / \mathrm{ml}$. streptomycin was added to the medium to inhibit the donor (Pearce \& Meynell, 1967) and it was observed that the plates without tryptophan used for scoring try ${ }^{+}$recombinants were covered with non-recombinant bacterial growth in contrast to those in which either proline or histidine had been omitted. This indicated considerable crossfeeding for tryptophan and suggested that the high incidence of try ${ }^{+}$recombinants might have resulted from mating on the plates. However, when strain J6-2 str-r was replaced as recipient by strain X 195 carrying $\mathrm{pyrF}^{-}$and $\mathrm{purB}^{-}$, loci closely linked to try ${ }^{-}$, and the concentration of streptomycin was increased to $5000 \mu \mathrm{g} . / \mathrm{ml}$, , the numbers of $p y r F^{+}$and $p u r B^{+}$recombinants were as high as those of $t r y^{+}$recombinants, although when adenine or uracil was omitted there was no background growth, and presumably no cross-feeding and continued mating on the plates. Moreover, when the derepressed mutant of $\mathrm{R}_{\mathrm{I}}$, which gives a much higher rate of conjugation, was substituted for wild-type $\mathrm{R} \mathrm{I}$, try ${ }^{+}$recombinant colonies could be counted after plating dilutions of the mating mixture which did not give any background growth.

Table 2 shows the frequencies of the different recombinant classes obtained with the various conjugation factors. With $F$, the frequency of recombinants for all markers was $\mathrm{I} \times \mathrm{IO}^{-5}$ to $2 \times 1 \mathrm{IO}^{-4}$ and, although it was not unusual to find more recombinants for pur $F$, try or pur $B$ than for other loci, the difference was seldom more than twofold. The small numbers of pro $^{+}$recombinants using strain $\mathrm{J}_{5-3} \mathrm{met}^{-} \mathrm{pro}^{-}$as donor was 


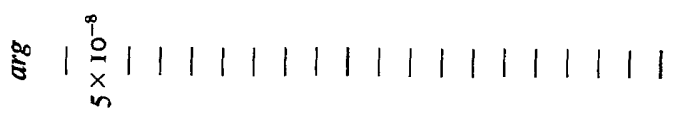

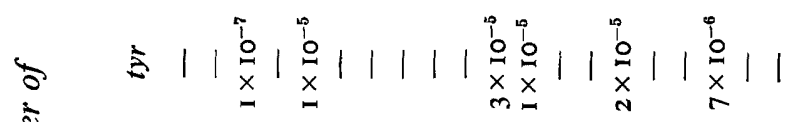

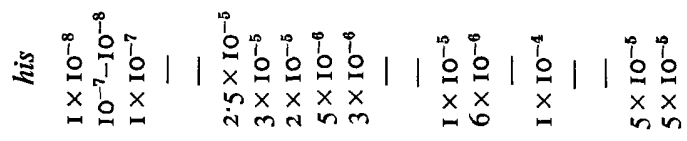

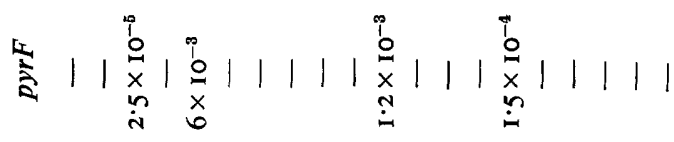

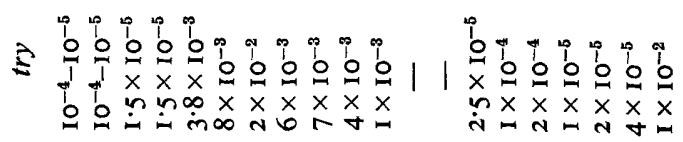

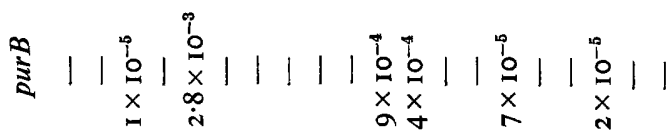

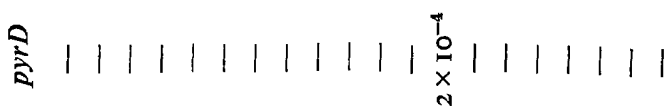

產

胥䓌



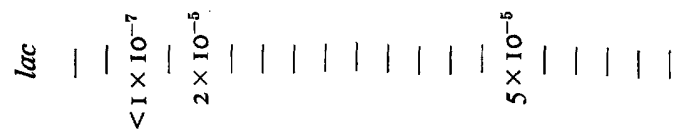

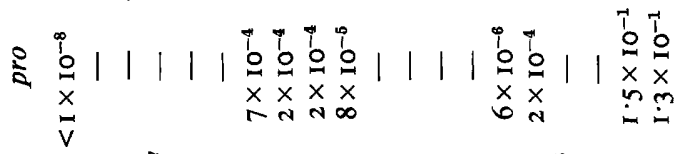

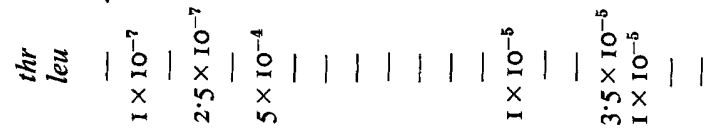

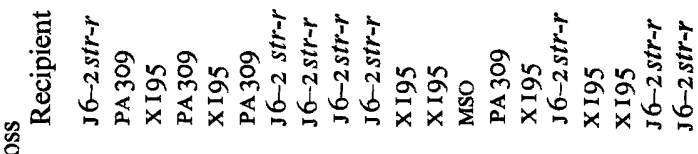

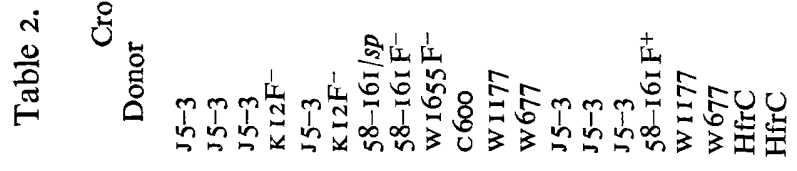

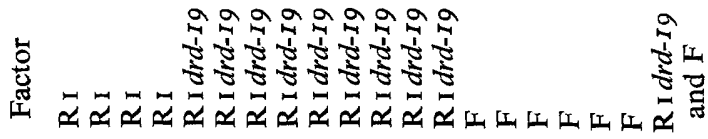


due to close linkage of $p r o^{-}$in donor and recipient. With $\mathrm{R} \mathrm{I}$, recombinants for $p y r F^{+}$, try $y^{+}$and purB $B^{+}$occurred at a frequency of $\mathrm{IO}^{-4}$ to $\mathrm{IO}^{-5}$, about 100 times higher than for other markers.

$\mathrm{R}_{\mathrm{I}} d r d-\mathrm{I} 9$ is a mutant of the wild type $\mathrm{R}_{\mathrm{I}}$ in which conjugation is no longer repressed (Meynell \& Datta, I967). The frequency of recombinants for chromosomal genes with R I drd-19 was increased to the same extent as the frequency of conjugation

Table 3. Escherichia coli KI2: comparison of recombination between strain $55-3$ as donor and strain $X I 95$ as recipient mediated by $R I$ drd-I9, wild-type $R I$ and $F$

Ratio of

frequencies Ratios of frequencies of selected recombinants

Factor

$$
\text { of } R
$$

transfer

lac purB try pyrF tyr

$\mathrm{R}$ I $d r d$-I 9 compared with $\mathrm{F}$

$\begin{array}{rrrrr}\text { lac } & \text { purB } & \text { try } & \text { pyrF } & \text { tyr } \\ \mathrm{I} & 42 & 29 & 46 & \text { I } \\ - & 343 & 280 & 325 & - \\ - & 8 & 9 & 7 & -\end{array}$

R I drd-I9 compared

$\begin{array}{rrr}- & 1 & 42 \\ 250 & - & 343 \\ - & -\end{array}$

Table 4. Escherichia coli KI2: patterns of segregation of unselected markers in crosses between $J 5-3$ and $X 195$

\begin{tabular}{|c|c|c|c|c|c|c|c|c|c|c|}
\hline \multicolumn{5}{|c|}{ Pattern of segregation of markers } & \multicolumn{4}{|c|}{$\begin{array}{l}\text { Recombinants } \\
\text { with } \\
\text { J5-3 (R I } d r d-19)\end{array}$} & \multicolumn{2}{|c|}{ J5-3(R I) } \\
\hline lac & purB & try & pyrF & tyr & No. & $\%$ & No. & $\%$ & No. & $\%$ \\
\hline $\mathbf{S}$ & 0 & $\circ$ & 0 & o & 39 & $67 \cdot 2$ & 48 & $55 \cdot 75$ & - & - \\
\hline $\mathbf{S}$ & I & I & 1 & 0 & 14 & $24 \cdot 0$ & 29 & $33 \cdot 7$ & - & - \\
\hline $\mathbf{S}$ & I & 0 & 0 & 0 & 3 & $5 \cdot 0$ & 3 & 3.5 & - & - \\
\hline $\mathbf{S}$ & I & I & 0 & 0 & 2 & 3.4 & I & $I \cdot 15$ & - & - \\
\hline $\mathbf{S}$ & 0 & 0 & I & 0 & 0 & 0 & 2 & $2 \cdot 3$ & - & - \\
\hline$S$ & 0 & I & I & 0 & 0 & 0 & 2 & $2 \cdot 3$ & - & - \\
\hline $\mathbf{S}$ & I & 0 & I & 0 & 0 & 0 & I & $I \cdot 15$ & - & 一 \\
\hline 0 & $\mathbf{S}$ & 0 & 0 & 0 & $2 I$ & 34.4 & I I & I2.6 & 6 & 9.5 \\
\hline 0 & $\mathbf{S}$ & I & 0 & 0 & 2 & 3.3 & 3 & 3.45 & 2 & $3 \cdot 2$ \\
\hline 0 & $\mathbf{S}$ & I & I & 0 & 18 & 29.5 & 69 & $79 \cdot 3$ & 53 & 84.0 \\
\hline 0 & $\mathbf{S}$ & 0 & I & 0 & I & $\mathrm{I} \cdot 6$ & $I$ & $\mathrm{I} \cdot 15$ & I & $\mathrm{I} \cdot 6$ \\
\hline I & $\mathbf{S}$ & I & 1 & 0 & 9 & I 4.7 & 2 & $2 \cdot 3$ & I & I.6 \\
\hline I & $\mathbf{S}$ & I & 0 & 0 & 4 & 6.5 & I & $I \cdot I 5$ & 0 & 0 \\
\hline I & $\mathbf{S}$ & 0 & 0 & 0 & 4 & $6 \cdot 5$ & 0 & 0 & 0 & 0 \\
\hline 0 & $\mathbf{S}$ & 0 & 0 & I & 2 & $3 \cdot 3$ & 0 & 0 & 0 & 0 \\
\hline 0 & I & S & I & 0 & 30 & $49 \cdot 2$ & 29 & $33 \cdot 7$ & 22 & $40 \cdot 7$ \\
\hline 0 & 0 & $\mathbf{S}$ & I & 0 & 23 & $37 \cdot 7$ & 49 & $57^{\circ} \mathrm{O}$ & 28 & $5 \mathrm{I} \cdot 8$ \\
\hline 0 & I & $\mathbf{S}$ & 0 & 0 & I & $\mathrm{I} \cdot 6$ & 3 & 3.5 & 0 & 0 \\
\hline I & I & $\mathbf{S}$ & I & 0 & 6 & $9 \cdot 8$ & 0 & 0 & 0 & 0 \\
\hline 0 & 0 & $\mathbf{S}$ & 0 & 0 & I & $I \cdot 6$ & 5 & $5^{\cdot 8}$ & 4 & $7 \cdot 4$ \\
\hline 0 & I & I & $\mathbf{S}$ & 0 & 25 & $43 \cdot 0$ & 23 & $26 \cdot I$ & $2 \mathrm{I}$ & 30.0 \\
\hline 0 & 0 & I & $\mathbf{S}$ & 0 & 14 & 24.0 & 50 & $56 \cdot 8$ & 28 & 40.0 \\
\hline 0 & 0 & 0 & $\mathbf{S}$ & 0 & 7 & $12 \cdot 0$ & I3 & I 4.7 & 20 & 28.6 \\
\hline 0 & I & 0 & $\mathbf{S}$ & 0 & 0 & 0 & I & $\mathrm{I} \cdot 15$ & 0 & 0 \\
\hline I & I & I & $\mathbf{S}$ & 0 & 12 & $20 \cdot 6$ & I & $\mathrm{I} \cdot \mathrm{I} 5$ & I & I. 4 \\
\hline 0 & 0 & 0 & 0 & $\mathbf{S}$ & 52 & 88.0 & 24 & $43 \cdot 7$ & 5 & 100.0 \\
\hline 0 & I & I & I & $\mathbf{S}$ & 5 & 8.4 & 25 & $45 \cdot 45$ & 0 & 0 \\
\hline 0 & 0 & I & I & $\mathbf{S}$ & 2 & $3 \cdot 4$ & 3 & 5.4 & 0 & 0 \\
\hline 0 & I & I & 0 & $\mathbf{S}$ & 0 & 0 & 2 & 3.6 & 0 & 0 \\
\hline 0 & I & 0 & 0 & $\mathbf{S}$ & 0 & 0 & I & $\mathrm{I} \cdot 3$ & 0 & 0 \\
\hline
\end{tabular}

$\mathrm{I}=$ allele inherited from donor; $\mathrm{O}=$ allele inherited from recipient (Lederberg, I95I); $\mathrm{S}=$ donor allele selected. 
measured by transfer of the $\mathbf{R}$ factor (Table 3), indicating that the numbers of genetic recombinants obtained with wild-type $\mathrm{R} I$ was limited principally because conjugation was infrequent. The mutant $\mathrm{R}$ I $d r d-I g$ behaved exactly like the wild-type $\mathrm{R}$ I in giving about roo times more recombinants for the chromosomal region $p y r F .$. try...pur $B$ than for other genes, and the relative frequencies of three classes of recombinants for genes $p y r F$, try and $p u r B$ were the same with $\mathrm{R} \mathrm{I} d r d-19$ as with $\mathrm{R} \mathrm{I} \mathrm{(Table} \mathrm{2).} \mathrm{Chromosomal}$ recombinations brought about by the $\mathrm{R}$ factor could therefore be compared directly with that due to the sex-factor $\mathrm{F}$, provided that the mutant $\mathrm{R}$ I $d r d-\mathrm{I} 9$ was used, for then the frequencies of recombinant production were then no longer complicated by repression of mating in the wild type. In Table $3, \mathrm{R}$ I, R I $d r d-19$ and F are compared in crosses between strain J5-3 as donor and strain X 195 as recipient. $\mathrm{R}$ I $d r d-19$ gave nearly as many recombinants as $\mathrm{F}$ for genes outside the try region, but about 30 times more for $p y r F$, try and $\operatorname{pur} B$. The same relationship between the numbers of recombinants for the markers $p y r F$, try and pur $B$, and for other markers was observed with all lines of $E$. coli $\mathrm{K}$ I 2 tested as donors (Table 2).

\section{Unselected markers}

The patterns of segregation of unselected markers are shown in Tables 4 and 5 . Most of the alleles were those of the $\mathrm{R}^{-}$parent indicating that, as with the $\mathrm{F}$ factor,

Table 5. Pattern of segregation of unselected markers in crosses between $\mathrm{F}^{+}$and $\mathrm{RI}^{+}$donor strains and strain $\mathrm{PA} 309$

\begin{tabular}{|c|c|c|c|c|c|c|c|c|c|c|c|c|c|c|c|}
\hline \multirow{2}{*}{\multicolumn{10}{|c|}{ Pattern of segregation of markers }} & \multicolumn{6}{|c|}{ Recombinants with } \\
\hline & & & & & & & & & & \multicolumn{2}{|c|}{$\overbrace{}^{58-161(F)}$} & \multicolumn{2}{|c|}{$\overbrace{}^{\mathrm{J} 5-3(\mathrm{~F})}$} & \multicolumn{2}{|c|}{${ }^{\mathrm{J}} \underbrace{-3}(\mathrm{R} \mathrm{I})$} \\
\hline str & mal & $x y l$ & man & met & $\arg$ & $\begin{array}{l}\text { thr } \\
\text { leu }\end{array}$ & lac & try & his & No. & $\%$ & No. & $\overbrace{\%}$ & No. & $\overbrace{\%}$ \\
\hline $\mathrm{C}$ & 0 & 0 & 0 & $\mathrm{C}$ & $\mathbf{S}$ & 0 & 0 & 0 & 0 & - & - & - & - & 8 & $57 \cdot 15$ \\
\hline $\mathrm{C}$ & $\circ$ & $\circ$ & o & C & S & I & 0 & o & 0 & - & - & - & - & 3 & \\
\hline $\mathrm{C}$ & 0 & o & 0 & $\mathrm{C}$ & $\mathbf{S}$ & I & I & I & I & - & - & - & - & 2 & $14 \cdot 3$ \\
\hline $\mathrm{C}$ & 0 & 0 & 0 & $\mathrm{C}$ & $\mathbf{S}$ & o & 0 & o & I & - & - & - & - & $\mathbf{I}$ & $7 \cdot 15$ \\
\hline $\mathrm{C}$ & 0 & o & o & $\mathrm{C}$ & 0 & $\mathbf{S}$ & 0 & o & 0 & 27 & $96 \cdot 4$ & $\mathrm{I} 4$ & $100 \cdot 0$ & 5 & $50 \cdot 0$ \\
\hline $\mathrm{C}$ & o & o & 0 & $\mathrm{C}$ & 0 & $\mathbf{S}$ & 0 & 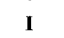 & 0 & I & $3 \cdot 6$ & 0 & 0 & 3 & 0.0 \\
\hline $\mathrm{C}$ & o & o & 0 & $\mathrm{C}$ & I & $\mathrm{s}$ & o & I & 0 & o & 0 & o & o & I & $10 \cdot 0$ \\
\hline $\mathrm{C}$ & o & o & 0 & $\mathrm{C}$ & I & $\mathbf{S}$ & 0 & 0 & 0 & 0 & o & 0 & 0 & I & $10 \cdot 0$ \\
\hline $\mathrm{C}$ & 0 & 0 & 0 & $\mathrm{C}$ & 0 & o & 0 & $\mathrm{~S}$ & 0 & 75 & $77 \cdot 4$ & 37 & $90 \cdot 0$ & 233 & $92 \cdot 0$ \\
\hline $\mathrm{C}$ & I & 0 & o & $\mathrm{C}$ & 0 & 0 & 0 & $\mathrm{~S}$ & 0 & 0 & 0 & 0 & 0 & 7 & $2 \cdot 7$ \\
\hline $\mathrm{C}$ & 0 & o & I & $\mathrm{C}$ & 0 & 0 & 0 & $\mathbf{S}$ & o & 0 & 0 & 0 & 0 & 4 & 1.58 \\
\hline C & 0 & 0 & 0 & C & 0 & 0 & 0 & $S$ & I & 4 & $4 \cdot I$ & 4 & $10 \cdot 0$ & 0 & 0 \\
\hline C & 0 & 0 & 0 & C & 0 & I & 0 & $S$ & I & 0 & 0 & 0 & 0 & I & 0.39 \\
\hline C & 0 & 0 & 0 & C & 0 & I & 0 & S & 0 & I8 & 18.55 & 0 & 0 & 8 & $3 \cdot 15$ \\
\hline C & 0 & 0 & 0 & C & 0 & 0 & 0 & 0 & $\mathrm{~S}$ & 6 & $75^{\circ} 0$ & $\ldots$ & - & 4 & $57 \cdot 0$ \\
\hline C & 0 & 0 & 0 & C & 0 & 0 & 0 & I & $\mathrm{S}$ & 2 & 25.0 & - & - & I & I 4.3 \\
\hline C & 0 & 0 & 0 & C & I & 0 & 0 & I & S & 0 & - & - & - & I & 14.3 \\
\hline C & 0 & 0 & 0 & C & 0 & I & 0 & 0 & $S$ & 0 & 0 & - & - & I & 14.3 \\
\hline
\end{tabular}

$\mathrm{I}=$ allele inherited from donor $\mathrm{O}=$ allele inherited from recipient (Lederberg, 195I); $\mathrm{S}=$ donor allele selected; $\mathrm{C}=$ donor allele contraselected.

transfer occurred from the $\mathrm{R}^{+}$to the $\mathrm{R}^{-}$cell. In the initial experiments, not shown in Tables 4 and 5, with wild-type R I, using strain $\mathrm{J}$ 6-2 str-r pro- his ${ }^{-}$try $y^{-} l a c^{-}$as recipient, only 6 out of 196 recombinants selected for $t r y^{+}$also received $l a c^{+}$, and when $p y r F$, 
try or pur $B$ were selected, the chromosome fragment transferred did not often extend beyond this region. The relative numbers of recombinants for $p y r F$, try and pur $B$ (Table 2) suggest that these three genes were transferred in ordered fashion $0 . . . p y r F \ldots$ try...pur $B$, starting from a fixed origin as in an Hfr strain; further support for a fixed gradient of transfer, in which pyrF regularly preceded pur $B$, was provided by the observation that amongst recombinants selected for pur $B^{+}$(the distal marker), 80$90 \%$ were also $\mathrm{pyrF}^{+}$, whereas only $30 \%$ of the recombinants selected for $\mathrm{pyrF} \mathrm{F}^{+}$ received pur $^{+}$. A strain, Mso, mutated in $\operatorname{pyr} D$, situated about the same distance as pyrF to the other side of purB (Signer et al. 1965), was kindly provided by Dr J. Shapiro, and when crossed with strain J 5-3 (R I $d r d-19$ ), pyr $D^{+}$recombinants were produced at intermediate frequency, as expected (Table 2 ).

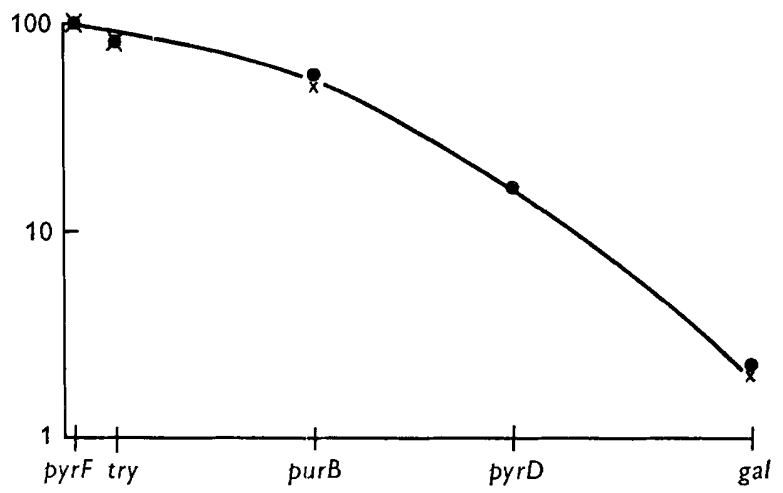

Fig. 2

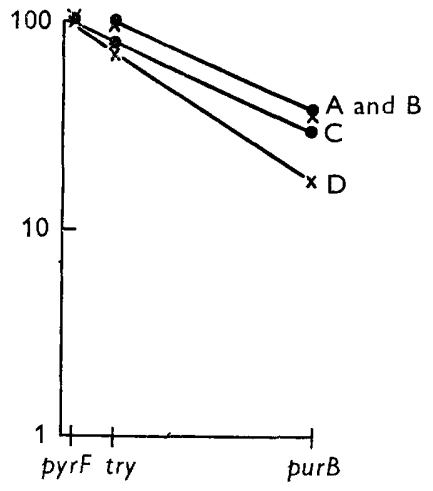

Fig. 3

Fig. 2. Comparison of the relative frequencies of recombinants for $p y r F, \operatorname{try}, p u r B, p y r D$ and gal with $\mathrm{J} 5-3$ (R I $d r d-19)$ and HfrB Io as donors. The crosses, J 5-3 (RI $d r d-19$ ( $\times$ X I95 and HfrB IO X X 195, were performed as described in Methods, the mating mixtures being diluted $\mathrm{I} / \mathrm{IOO}$ after $5 \mathrm{~min}$., and then allowed to stand for $\mathrm{I} \mathrm{hr}$ before blending and plating. Map distances on the abscissa are as proposed by Signer et al. (1965), and the percentage of recombinants obtained with J 5-3 (R I $d r d-I 9)(\odot)$ and $\mathrm{HfrB} I O(\times)$, relative to the frequency of $p y r F$ recombinants in each case, are plotted on a logarithmic scale.

Fig. 3. Comparison of the frequencies of inheritance of the donor try and purB genes as unselected markers in recombinants selected for $p y r F$, and of the frequency of pur $B$ in recombinants selected for try, with J 5-3 (R I $d r d-19)$ and HfrB IO as donors. The percentage of recombinants with the marker in the cross J 5-3 (R Idrd-I9) $\times$ XI95 (0) and the cross HfrB IO XXI95 $(\times)$ are plotted on a logarithmic scale, the map distances on the abscissa being those proposed by Signer et al. (1965). Curves A and B selected marker try; curves C and $\mathrm{D}$ selected marker pyrF.

\section{Comparison of strain $55-3(R I d r d-19)$ with an Hfr strain}

The donor behaviour of strain J 5-3 (R I $d r d-19$ ) was compared with that of an $\mathrm{Hfr}$ strain by using $\mathrm{HfrB}$ I0, which transfers in the order 0...try...lac...pro...(Broda, 1967) and which is therefore likely to initiate chromosome transfer near the presumptive origin of strains carrying $\mathrm{R}$ I $d r d-I 9$.

Crosses of the donors HfrB Io and $\mathrm{J}_{5-3}$ (R I $\left.d r d-19\right)$ with the recipient XI95 are compared in Figs. 2 and 3. In Fig. 2 the relative frequencies of recombinant classes selected for $\operatorname{pyr} F, \operatorname{tr} y, \operatorname{pur} B, \operatorname{pyr} D$ and gal are plotted logarithmically against the corresponding map distances as determined by Signer et al. (1965), and it can be seen that although the gradient of transfer was steeper than the simple exponential function 
of distance from the origin (de Haan \& Gross, I962), precisely the same gradient was observed with $\mathrm{J}_{5-3}(\mathrm{R} \mathrm{I} d r d-19)$ as with HfrB I0. Figure 3 shows the proportion of recombinants selected for the proximal gene, $p y r F$, that also received try and pur $B$, and the proportions selected for try that received pur $B$. Once again, essentially the same result is given by the two donor strains.

\section{Times of entry of pyrF and pur $B$ genes}

The production of $\mathrm{pyrF}^{+}$and pur $\mathrm{B}^{+}$recombinants was measured in a cross between J 5-3 (R I $d r d-19$ ) and X 195 with interrupted mating. Figure 4 shows the curves obtained when successive samples were plated for recombinants inheriting $p y r F^{+}$and $p u r B^{+}$. Extrapolating the ascending parts of the curves back to the abscissa to measure the time taken for transfer of a particular segment of chromosome (Wollman \& Jacob,

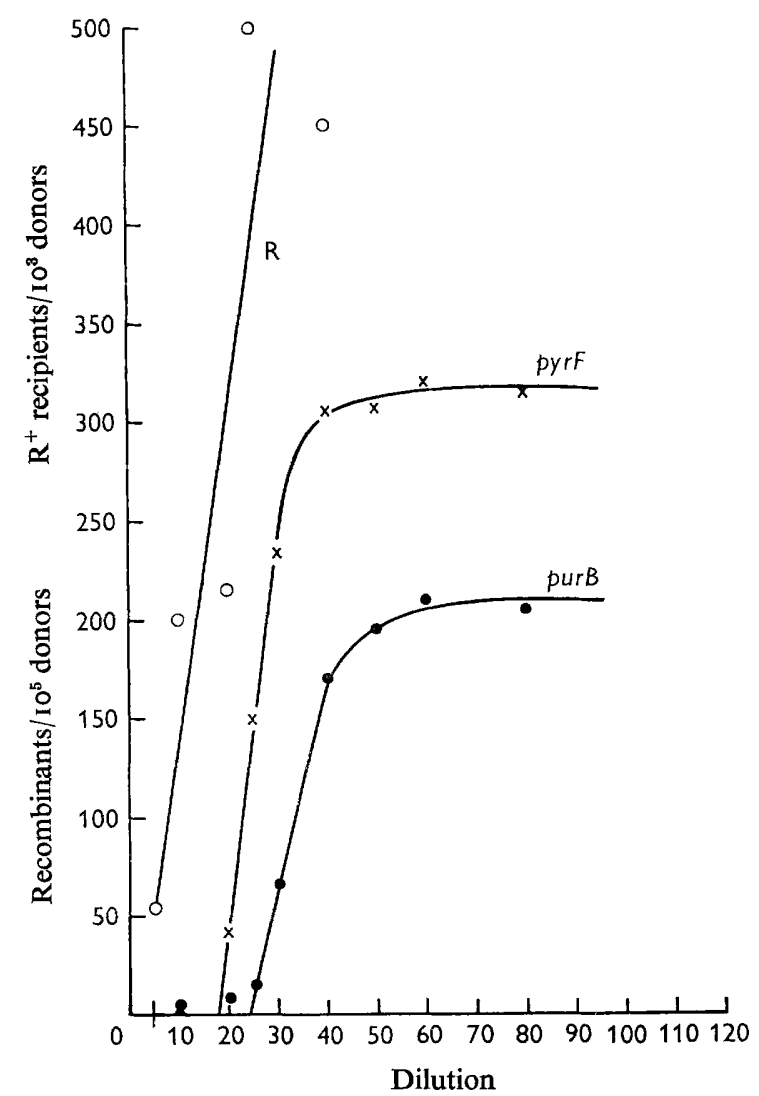

Fig. 4. Times of entry of $p y r F$ and $p u r B$ genes. The mating mixture consisted of $\mathrm{J}_{5-3}$ ( $\mathrm{R}_{\mathrm{I}}$ $d r d-19) 5 \times 10^{7} / \mathrm{ml}$. and $\times 1955 \times 10^{8} / \mathrm{ml}$. and was diluted $1 / 100$ into fresh broth after $5 \mathrm{~min}$. Samples taken at the times given on the abscissa were blended and then plated for recombinants inheriting $\operatorname{pyrF}^{+}(x)$ and purB $B^{+}(0)$, which are plotted as number of recombinants per $10^{5}$ donor cells. The number of pur $B^{+}$recombinants, 350 per $10^{5}$ donors, produced by a sample of the mating mixture which had been incubated without dilution for $120 \mathrm{~min}$., showed that at least half of the total possible number of cell pairs had formed within $5 \mathrm{~min}$. The curve for $R$ factor transfer $(O)$ plotted as number of $R^{+}$recipients per $10^{3}$ donors was obtained by plating samples on defined medium fully supplemented for growth of strain $\mathrm{X}$ I95 and containing chloramphenicol $20 \mu \mathrm{g} . / \mathrm{ml}$. 
1958; Wollman, Jacob \& Hayes, I956), the times of entry for $p y r F^{+}$and $p u r B^{+}$ recombinants were shown to be separated by $6 \mathrm{~min}$. The rare recombinant colonies appearing in the earliest samples presumably arose from mating pairs which had failed to separate. The maximum number of recombinants for $p y r F$ was reached by about 40 min., and for purB by about 50 min., and by that time, there were about $1 \cdot 6$ times as many for $p y r F$ as for $p u r B$, which agreed more or less with the relative numbers obtained when mating was uninterrupted for $60 \mathrm{~min}$.

Figure 3 also shows the curve for $\mathrm{R}$ transfer. The actual numbers of drug-resistant colonies differed somewhat between experiments, depending largely on the time allowed for the $\mathrm{R}^{+}$recipient cells to express their resistance before plating on medium containing the drug. However, the shapes did not differ significantly.

\section{Behaviour of an Hfr strain also carrying $R I$ drd-I9}

The orientation of chromosomal transfer by Hfr donors is determined by the position of the sex-factor $\mathrm{F}$. In strain $\mathrm{HfrC}$, where $\mathrm{F}$ is between pro and gal, pro is one of the first genes to be transferred and try one of the last. Thus, many recombinants inherit the pro gene of the donor, whereas very few acquire try. Crosses were made between $\mathrm{HfrC}$, both $\mathrm{R}^{-}$and carrying $\mathrm{R}_{\mathrm{I}} d r d-\mathrm{I}$, and strain $\mathrm{J} 62$ str-r allowing $5 \mathrm{~min}$. for cell contacts to form and then incubating a r/roo dilution of the mixture for 60 min. before blending and plating to select rro $^{+}, h i s^{+}$and $t r y^{+}$recombinants. The presence of $\mathrm{R} \mathrm{I} d r d-19$ in HfrC did not appreciably alter the frequency of pro ${ }^{+}$recombinants (Table 2); however, the number of try $^{+}$recombinants increased about 250 -fold, and thus the $\mathrm{R}$ factor evidently directed the transfer of this particular chromosomal segment in $\mathrm{HfrC}$ just as it did in an $\mathrm{F}^{-}$strain. When wild-type $\mathrm{R}_{\mathrm{I}}$ was present in $\mathrm{HfrC}$, the results were altogether comparable to those with $\mathrm{R} \mathrm{I} d r d-19$, although the effect was masked to a large extent by the repression which $\mathrm{R}$ I exerts on conjugation, which greatly lowered the numbers of all classes of recombinants.

\section{DISCUSSION}

Although genetic recombinants for chromosomal markers are known to be produced during conjugation brought about by $\mathbf{R}$ factors (Sugino \& Hirota, 1962), a distinction is drawn between conjugation factors like $\mathrm{R}$ factors and col I (Ozeki, Howarth \& Clowes, I96I) on the one hand, and F on the other, in that recombination is more frequent with $\mathrm{F}$. The number of recombinants, however, necessarily depends on the number of bacteria that conjugate, and both $\mathrm{col} \mathrm{I}$ and $\mathrm{R}$ factors also differ from $F$ in producing a repressor which prevents synthesis of the specific pilus, and thus conjugation, in all but a small minority of bacteria (Stocker, Smith \& Ozeki, I963; Monk \& Clowes, 1964; Meynell \& Datta, 1966a; Meynell \& Lawn, 1967). In the case of R I at least, the lower rate of recombination observed with the wild-type $\mathrm{R}$ factor was largely due to less frequent mating, as was shown by using a mutant, R I $d r d-r 9$, which does not produce repressor (Meynell \& Datta, 1967).

The striking feature of recombination with $R I$ is the relatively high frequency with which the try region of the donor chromosome appears among recombinants. This peculiarity of $\mathrm{R} I$ was difficult to analyse with the wild-type $R$ factor, since it gave few recombinants of any kind, but using the de-repressed mutant $\mathrm{R}_{\mathrm{I}} d r d-\mathrm{r} g$ it became clear that a genetic donor carrying $\mathrm{R}$ I transferred the bacterial chromosome as though 
it were an Hfr strain with the $\mathrm{F}$ factor integrated between the try region and his, not far from $p y r F$. This phenomenon is distinct from the high frequency of recombinants for met, reported by Sugino \& Hirota (1962), when R factors bring about conjugation in the Richter $q_{3}$ strains. The $q_{3}$ strain, though losing ability to conjugate, nevertheless retained the chromosomal origin near met characteristic of its parent Hfr strain (Richter, I96I); thus, when conjugation factors are introduced which restore its donor ability, recombinants for met are produced at high frequency. The same thing is observed when 'F-refractory' Hfr strains (Lederberg \& Lederberg, 1956) are infected with R factors (Hirota, Fujii \& Nishimura, I966). With R I, on the other hand, the oriented transfer of the try region is a characteristic feature of the $\mathrm{R}$ factor and is independent of the particular bacterial strain used as donor.

Using as recipients with $\mathrm{R} \mathrm{I}^{+}$donors, strain X $195 \mathrm{pyrF}^{-}$try- pur $B^{-}$which was also $\mathrm{gal}^{-}$and the uracil-requiring strain $\mathrm{MSO} \mathrm{pyrD}^{-}$, it was possible to show that the relative numbers of recombinants inheriting the various donor markers between $p y r F$ and gal coincided with their order on the genetic map as determined by Signer $e$ t al. (1965). That the order of transfer was pyrF...try...purB...gal, starting from a fixed origin, was supported by the patterns of unselected markers. Most recombinants selected for the more distal $\operatorname{pur} B$, also acquired the proximal $p y r F$; but selected for $p y r F$, fewer recombinants had purB. Finally, by using the de-repressed mutant, $\mathrm{R} \mathrm{I} d r d-\mathrm{I}$, an $\mathrm{RI}^{+}$donor could be directly compared with a known Hfr strain, and also examined in an interrupted mating experiment for the relative times of entry of $p y r F$ and $\operatorname{pur} B$. These tests showed that an $\mathrm{RI}^{+}$donor transferred its chromosome in the way associated with the Hfr state. There were, however, two differences. First, recombinants were rather fewer; this may be misleading, as pointed out above, since, in comparing recombination rates with different conjugation factors, one may in reality be comparing the frequencies at which conjugation takes place, rather than chromosome transfer itself. Second, and more important, the recombinants had nearly always received the $\mathrm{R}$ factor also. These are precisely the two features which distinguish recombination brought about by $\mathrm{F}^{\prime}$ factors such as $\mathrm{F} 2$ (Adelberg \& Burns, I960) which alternate rapidly between the autonomous state and integration at a particular chromosomal site, from recombination with a typical Hfr donor where the only $\mathrm{F}$ factor present is integrated and seldom transferred. The relative frequencies of sexfactor transfer and production of the most frequent class of recombinant with RI are altogether comparable to those reported for F 2 by Adelberg \& Burns (I960). RI thus appears as another genetic element with a specific affinity for a particular chromosomal site, which it probably acquired in the same way as an $\mathrm{F}^{\prime}$ factor; that is, by recombination with the chromosome of a previous host. The ultimate source of the resistance determinants carried by $\mathrm{R}$ factors remains unknown, but the region of $\mathrm{R} I$ homologous with the chromosome did not lie in its resistance genes: one segregant without kanamycin-resistance, as well as another which lost all except resistance to kanamycin, continued to give large numbers of recombinants for the try region as before. If the homologous region of $\mathrm{R}_{\mathrm{I}}$ is indeed associated with the conjugation factor proper, it is worth noting that its site of integration is one of those where $\mathrm{F}$ integrates (to give the Hfr strain HfrB Io described by Broda, 1967).

Integrated and autonomous $\mathrm{F}^{\prime}$ factors can co-exist in the same cell because of the instability of chromosomal attachment, which does not last long enough to cause the autonomous $\mathrm{F}$ to disappear (Adelberg \& Burns, 1960). Presumably the same explana- 
tion applies to $\mathrm{R} I$, which must therefore alternate frequently between the integrated and the autonomous state. Transient integration, if it lasted for a few generations, might lead to detectable fluctuation in the numbers of recombinants produced by different donor cultures, provided that young enough cultures were examined. In fact, a significant degree of variation appeared in an experiment where replicate $\mathrm{I} \mathrm{ml}$. broth cultures of J 5-3 (R I $d r d-19$ ) grown from an inoculum of 200 bacteria $/ \mathrm{ml}$. to a concentration of $2 \times 10^{5} / \mathrm{ml}$. were tested for the production of $p y r F^{+}$recombinants after mixing with strain $\times 195$ at $5 \times 10^{8} / \mathrm{ml}$. for $\mathrm{I} \mathrm{hr}$. When 19 individual $0.02 \mathrm{ml}$. samples from each of two cultures were plated, the average numbers of recombinants were $I 5.3$ and $I 6.5$ with variances of $I 4 . I$ and 19.5 equal to 0.92 and $I .2$ times the mean respectively. However, with single samples from each of 130 further cultures, the average number of recombinants was 12.47 and the variance $40 \cdot 7$; that is, considerably greater than the mean, as expected for a non-random distribution.

The frequency with which different Hfr types arise, as well as their stability, depends directly on the length of the homologous region (Broda, 1967) and, on this argument, the region in R I homologous with the chromosome of Escherichia coli $\mathrm{K} I 2$ should be of considerable length. The members of that class of $\mathrm{R}$ factors comprising $\mathrm{R}$ I so resemble each other and the $\mathrm{F}$ factor in the conjugation pilus and the genetic control of its synthesis that all are likely to have evolved from a common ancestor (Meynell \& Datta, 1966a). Nevertheless, the conjugation factor of $\mathrm{R} \mathrm{I}$ is not F itself, for, apart from several perhaps only insignificant differences such as in susceptibility to acridines and in restriction of different phages (see Watanabe, 1966) they manifest no superinfection immunity towards each other. In contrast to the mutual exclusion between two F factors (Scaife \& Gross, 1962), or between F and col V (Macfarren, 1966), bacteria carrying either $\mathbf{F}$ or $\mathbf{R}$ I readily accept the other, and both factors are able to co-exist stably in the same cell.

The characteristic behaviour of $\mathrm{R} \mathrm{I}$ in an $\mathrm{F}^{-}$strain could also be observed with $\mathrm{Hfr}$ bacteria, although here again it was necessary to use the de-repressed mutant to avoid repression of conjugation mediated by $\mathrm{F}$ as well as by $\mathrm{R}$. When $\mathrm{R}$ I $d r d-r 9$ was introduced into $\mathrm{HfrC}$, two kinds of recombinant were produced at high frequency, the usual pro recombinants resulting from the oriented transfer of the Hfr chromosome and, superimposed on these, the try recombinants due to a second point of origin determined by the R factor. Strain HfrC (R I $d r d-r 9$ ) thus resembled the 'double male' strain of Clark (1963), which carries two $\mathrm{F}$ factors integrated at different chromosomal sites. Watanabe \& Ogata (1966) also refer to the similar behaviour of an Hfr strain carrying, as well as the integrated $\mathrm{F}$ factor, a particular hybrid of an $\mathrm{R}$ factor with $\mathrm{F}$.

It has been questioned whether the term 'episome' (Jacob \& Wollman, 1958) should be applied to conjugation factors like $c o l$ factors and $\mathrm{R}$ factors which have never been shown with certainty to integrate with the bacterial chromosome in the same way as the $\mathrm{F}$ factor (Clowes \& Moody, 1966). However, from the way in which R I brings about the transfer of the chromosome from the donor cell, it now seems that this is one $\mathbf{R}$ factor which may be described as an episome within the original definition.

One of us (L.E.P.) is indebted to the New Zealand Dairy Research Institute for a Fellowship held during the course of this investigation. 


\section{REFERENCES}

ADams, M. H. (1959). Bacteriophages. New York: Interscience Publishers Inc.

Adelberg, E. A. \& Burns, S. N. (1960). Genetic variation in the sex factor of Escherichia coli. J. Bact. 79, $32 \mathrm{I}$.

APPLEYARD, R. K. (1954). Segregation of new lysogenic types during growth of a doubly lysogenic strain derived from Escherichia coli $\mathrm{K} 12$. Genetics 39, 440.

Broda, P. (1967). The formation of Hfr strains in Escherichia coli K I2. Genet. Res., Camb. 9, 35.

Cavalli-Sforza, L. L. (1950). La sessualita nei batteri. Boll. Ist. sieroter. Milan 29, 28 I.

CLARK, A. J. (I963). Genetic analysis of a 'double male' strain of Escherichia coli K I2. Genetics 48, I05.

Clowes, R. C. \& Moody, E. D. M. (1966). Chromosomal transfer from 'recombination-deficient' strains of Escherichia coli K I2. Genetics 53, 7 I 7.

Clowes, R. C. \& Rowley, D. (1954). Some observations on linkage effects in genetic recombination in Escherichia coli $\mathrm{K}$ I2. J. gen. Microbiol. $\mathbf{1 1}, 250$.

HAAN, P. G. DE \& Gross, J. D. (1962). Transfer delay and chromosome withdrawal during conjugation in Escherichia coli. Genet. Res. Camb. 3, $25 \mathrm{I}$.

HaYes, W. (I953). Observations on a transmissible agent determining sexual differentiation in Bact. coli. J. gen. Microbiol. 8, 72.

Hirota, Y., FUJI, T. \& Nishimura, Y. (1966). Loss and repair of conjugal fertility and infectivity of the resistance factor and sex factor in Escherichia coli. J. Bact. 9r, I 298.

Jacob, F. \& Wollman, E. L. (1958). Les épisomes, éléments génétiques ajoutés. C. r. hebd. Séanc. Acad. Sci., Paris 247, I54.

LeDERBERG, E. M. \& LeDERBERG, J. (1953). Genetic studies of lysogenicity in Escherichia coli. Genetics $3^{8}, 5 \mathrm{I}$.

LEDERBERG, J. (1947). Gene recombination and linked segregations in Escherichia coli. Genetics 32, 505.

LEDERBERG, J. (1950). The selection of genetic recombinations with bacterial growth inhibitors. $J$. Bact. 59, 211 .

LEDERBERG, J. (I95I). Streptomycin resistance: a genetically recessive mutation. J. Bact. 6r, 549.

Lederberg, J., Cavalli, L. L. \& Lederberg, E. M. (1952). Sex compatibility in Escherichia coli. Genetics 37, 720.

Lederberg, J. \& Lederberg, E. M. (1956). Infection and heredity. In Cellular Mechanisms in Differentiation and Growth. Ed. by D. Rudrick, p. IOI. Princeton, N. J. : Princeton University Press.

LENNox, E. S. (1955). Transduction of linked genetic characters of the host by bacteriophage P I. Virology $\mathbf{1}, 190$.

MACFARREN, A. C. (1966). A study of three related colicin factors and their products. Ph.D. thesis; University of London.

Meynell, E. \& DatTA, N. (I966a). The relation of resistance transfer factors to the F factor of Escherichia coli K I2. Genet. Res., Camb. 7, 134.

Meynell, E. \& DatTA, N. (1966b). The nature and incidence of conjugation factors in Escherichia coli. Genet. Res., Camb. 7, I4I.

Meynell, E. \& Datta, N. (1967). Mutant drug resistance factors of high transmissibility. Nature, Lond. 214, 885.

Meynell, G. G. \& LAWn, A. M. (1967). Sex pili and common pili in the conjugational transfer of colicin factor Ib by Salmonella typhimurium. Genet. Res., Camb. (in the Press).

Monk, M. \& Clowes, R. C. (1964). The regulation of colicin synthesis and colicin factor transfer in Escherichia coli $\mathrm{K}$ I2. J. gen. Microbiol. 36, 385 .

Ozeki, H., HowarTh, S. \& Clowes, R. C. (I96I). Colicine factors as fertility factors in bacteria. Nature, Lond. I90, 986.

Ozeki, H., Stocker, B. A. D. \& SMith, S. (I962). Transmission of colicinogeny between strains of Salmonella typhimurium grown together. J. gen. Microbiol. 28, 67I.

Pearce, L. E. \& Meynell, E. (1968). Mutation to high level streptomycin-resistance in $\mathbf{R}^{+}$bacteria. J. gen. Microbiol. 50, 173. 
RICHTER, A. (I96I). Attachment of wild-type F factor to a specific chromosomal region in a variant strain of Escherichia coli $\mathrm{K}$ I 2 : the phenomenon of episomic alternation. Genet. Res., Camb. 2, 333.

SCAIFE, J. \& Gross, J. D. (1962). Inhibition of multiplication of an F-lac factor in Hfr cells of Escherichia coli K 12. Biochem. biophys. Res. Comm. 7, 403.

SHAPIRO, J. (1967). The structure of the galactose operon in Escherichia coli $\mathrm{K}$ I2. Ph.D. thesis; University of Cambridge.

Signer, E. R., BeCKWith, J. R. \& BRENNER, S. (I965). Mapping of suppressor loci in Escherichia coli. J. molec. Biol. I4, I53.

Stocker, B. A. D., Smith, S. M. \& Ozeki, H. (1963). High infectivity of Salmonella typhimurium newly infected by the col I factor. J. gen. Microbiol. 30, 201.

Sugino, Y. \& HiRota, Y. (1962). Conjugal fertility associated with resistance factor R in Escherichia coli. J. Bact. 84, 902.

TAtum, E. L. \& Lederberg, J. (1947). Gene recombination in the bacterium. J. Bact. 53, 673.

WATANABE, T. (1963). Infective heredity of multiple drug resistance in bacteria. Bact. Rev. $27,87$.

WATANABE, T. (1966). Evolutionary relationships of $\mathrm{R}$ factors with other episomes and plasmids. Fedn. Proc. 26, 23.

WATANABE, T. \& OGATA, C. (I966). Episome mediated transfer of drug resistance in Enterobacteriaceae. IX. Recombination of an R factor with F. J. Bact. 9I, 43.

Wollman, E. L. \& JACOB, F. (1958). Sur le processus de conjugaison et de recombinaison chez Escherichia coli. V. Le méchanisme du transfert de matériel génétique. Ann. Inst. Pasteur 95, 641.

Wollman, E. L., JACOB, F. \& Hayes, W. (I956). Conjugation and genetic recombination in Escherichia coli $\mathrm{K}$ 12. Cold Spr. Harb. Symp. quant. Biol. 21, I4I. 